\title{
THE EFFECT OF e-WOM AND BRAND IMAGE ON THE INTEREST IN BUYING THE HEAVENLY BLUSH YOGHURT PRODUCT
}

\author{
Muslih Mughoffar ${ }^{*}$, Ujang Sumarwan**), and Netty Tinaprilla***) \\ *) PT SUCOFINDO (Persero) \\ Jl. Raya Pasar Minggu Kav. 34, Jakarta, 12780 \\ ${ }^{* *}$ Department of Family and Consumer Sciences, Faculty of Human Ecology, IPB University \\ Jl. Kamper Kampus IPB Darmaga, Bogor 16680 \\ ${ }^{* * *)}$ Departement of Agribusiness, Faculty of Economics and Management, IPB University \\ Jl. Kamper, Wing 4 Level 5 Campus of IPB Darmaga Bogor 16680
}

\begin{abstract}
The objectives of this research are: 1) to analyze the effect of e-WOM on brand image of Heavenly Blush product, 2) to analyze the effect of e-WOM on the interest in buying Heavenly Blush product, and 3) to analyze the effect of brand image on the interest in buying Heavenly Blush product. This research used online and offline survey methods in the form of questionnaires. The research sampling was carried out using non-probability sampling technique. The scaling technique of the study applied Likert scale which produces measurements at intervals; scale 1 for strongly disagree statements and scale 5 for strongly agree statements. The data analysis used PLS (Partial Least Square). The 106 respondents of the research were customers who already knew about Heavenly Blush yogurt products but had never consumed them with the minimum age of 17 years. The findings showed that there is a positive effect of e-WOM variable on brand image variable with a value of 0.425 . The e-WOM variable has a positive effect on the interest in buying Heavenly Blush product with a value of 0.430 . Brand image is the last variable that has a positive effect on interest in buying with a value of 0.244 .
\end{abstract}

Keywords: brand image, e-WOM, interest in buying, product, yogurt

\begin{abstract}
Abstrak: Tujuan dari penelitian ini, yaitu 1) menganalisis pengaruh antara e-WOM terhadap citra merek produk Heavenly Blush, 2) menganalisis pengaruh e-WOM terhadap minat membeli produk Heavenly Blush, 3) Menganalisis pengaruh Citra Merek terhadap minat Membeli produk Heavenly Blush. Metode penelitian yang digunakan adalah survei online dan offline dalam bentuk kuesioner. Teknik pengambilan sampel dalam penelitian ini dilakukan dengan cara Non Probability Sampling. Teknik pemberian skala yang digunakan dalam penelitian ini adalah skala likert dan menghasilkan pengukuran secara interval yaitu skala 1 untuk pernyataan sangat tidak setuju dan skala 5 untuk pernyataan sangat setuju. Analisis data yang digunakan dalam penelitian ini menggunakan PLS (Partial Least Square). Responden yang diteliti adalah konsumen yang sudah mengetahui produk yogurt Heavenly Blush tetapi belum pernah mengkonsumsinya minimal usia 17 tahun. Responden yang diteliti sebanyak 106 responden. Hasil penelitian menunjukkan adannya pengaruh positif antara variabel e-WOM terhadap variabel citra merek dengan nilai pengaruh 0.425. Variabel e-WOM memiliki pengaruh positif terhadap minat membeli produk heavenly blush dengan nilai pengaruh sebesar 0.430. Citra merek merupakan variabel terakhir yang memiliki pengaruh positif terhadap minat membeli dengan nilai pengaruh sebesar 0.244.
\end{abstract}

Kata kunci: citra merek, e-WOM, minat membel, produk, yogurt

\footnotetext{
${ }^{1}$ Corresponding author:

Email: m.mughoffar@gmail.com
} 


\section{INTRODUCTION}

The development of the world of technology and communication like the internet has made it easier for people to consume and produce information. A survey conducted by the Indonesian Internet Service Provider Association (APJII) explained that more than 50 percent or about 143 million Indonesians were connected and used the internet as a medium of communication, business, and so forth.

When a consumer decides to buy a product based on information, recommendations, advice, or forms of invitation from other consumers, this relationship is referred to as Word of Mouth (WOM) (Maisam and Mahsa, 2016). According to Kotler and Keller (2011), WOM is marketing communication that relates to the experience of buying or using products and services which are carried out by an individual, in oral and written forms (Cheema and Kaikati, 2010). This form of marketing mix is expected to communicate information positively to other consumers (Yoo et al. 2000).

Word of Mouth is one of the new marketing communication processes; i.e. by giving recommendations personally to individual and group on a product or service that aims to provide information (Jatmika, 2014). The development of communication technology such as the internet and social media also participates in influencing the operational patterns of the WOM itself (Chan and Ngai, 2011). Therefore, the pattern of exchanging information and knowledge online on the internet and social media is known as Electronic Word-of-Mouth (e-WOM) (Charo et al. 2015).

Recommendations or reviews, given by consumers for their experience in a review platform or other channel forms, will affect the Brand Image and the Buying Interest of the consumers for the product (Ambarwati and Mawardi, 2015). It will be realized well if the consumer is satisfied with the product that he/she uses. They will express their customer satisfaction by disseminating positive information on contents related to the product (Kartika and Piranti, 2015). In this case, e-WOM can create a good brand image in the minds of consumers and increase buying interest (Samuel and Lianto, 2014). This is also based on previous research conducted by Laksmi and Oktavani (2016) who conducted research in Warung Upnormal and Jalilvand and Samiei (2012) who studied interest in one of the car industry brands in Iran. They found that e-WOM is an instrument for forming brand image and interest in buying of the consumers. Based on that description and previous research, the researchers want to find out whether the e-WOM concept would also affect brand image and interest in buying more complex products consumed by Indonesian people through online review content which is currently very viral.

One of the industries in Indonesia that is being developed and growing is the milk processing industry. Sanny (Rachman et al. 2017) predicted that the milk processing industry in Indonesia will increase by 10 percent per year. Along with the growth of the food and beverage industry that uses milk as the raw material and the increase of public awareness to the importance of the benefits of milk for health, it is an opportunity for processed dairy companies to create new variants of processed milk (Sanny, 2011).

Yoghurt, as a variant of processed milk, is a type of beverage derived from milk fermentation. The formation of yoghurt is caused by fermentation of sugar and milk which then becomes lactic acid (Needs et al. 2000). That is what makes yoghurt thick and has a distinctive sour taste (Resnawati, 2014), and it is not just about the unique and delicious taste. Furthermore, yoghurt has many beneficial ingredients. According to Ejtahed et al. (2012), yoghurt contains probiotics; i.e. functional foods that can provide antidiabetic and antioxidant efficacy.

Heavenly Blush is one of the companies that produce yoghurt in Indonesia. Heavenly Blush does not walk alone in the yoghurt market. In fact, there are several brands that have enlivened the yoghurt market in Indonesia; for instance, Activia and Cimory. However, Heavenly Blush yoghurt products have their own characteristics to be well accepted in the consumers' minds. Companies need to utilize the linkages of one marketing mix such as e-WOM to Heavenly Blush's product brand image and interest in buying. This can be used as the basis of marketer's strategy so that the company gets a great chance to continuously compete and be consistent in carrying out its business. Therefore, this research has several objectives which include: Analyzing the effect of e-WOM on the Heavenly Blush product brand image; Analyzing the effect of e-WOM on the Interest in Buying Heavenly Blush products; Analyzing the effect of Brand Image on the Interests in Buying Heavenly Blush products. 


\section{METHODS}

This research was conducted in Jabodetabek area (Jakarta, Bogor Depok, Tangerang, and Bekasi) from April to June 2018. The selection of location was based on the potential consumers of yoghurt in the area. The research approach used descriptive research. The main purpose of descriptive research is to describe the characteristics of an object person, group, and environment (Sumarwan et al. 2011). The data type is primary data. The research method is a survey in the form of a structured questionnaire. Survey research is a research design that collects data from a number of respondents selected from a population (Sumarwan et al. 2011). The survey was conducted by distributing online questionnaires using google.doc and direct interviews with respondents (offline).

The research sampling technique was conducted using Non-Probability Sampling with Purposive Sampling method in which the sample units were adjusted to certain criteria applied based on the research objectives (Tongco, 2007). The scaling technique used in this research was the Likert scale which produces measurements at intervals: scale 1 for strongly disagree statements and scale 5 for strongly agree statements.
The sample units of this research were consumers who already knew about Heavenly Blush yoghurt products but had never consumed them, and they were at least aged 17 years old. They were used to measure consumers' interest in yoghurt on Heavenly Blush products that they had never bought. There were 106 respondents involved in this research.

The data analysis in this research used PLS (Partial Least Square). PLS is one of the alternative methods of SEM (Structural Equation Modeling) that can be used to overcome problems in relation to variant or component-based approaches (Yamin and Kurniawan, 2009). PLS assumed the research data was free of distribution, meaning that the research data did not refer to one particular distribution (Mehmood et al. 2012). The purpose of PLS is to predict the effect of variable $\mathrm{X}$ on $\mathrm{Y}$ and explains the theoretical correlation between the two variables (Talbot, 1997). PLS is used to develop theories that aim to predict the correlation between e-WOM (Electronic Word of Mouth), brand image, and interest in buying Heavenly Blush products. Based on empirical studies, this research focused on the correlation of e-WOM, Brand Image and Interest in Buying which is presented in the research framework in the following Figure 1.

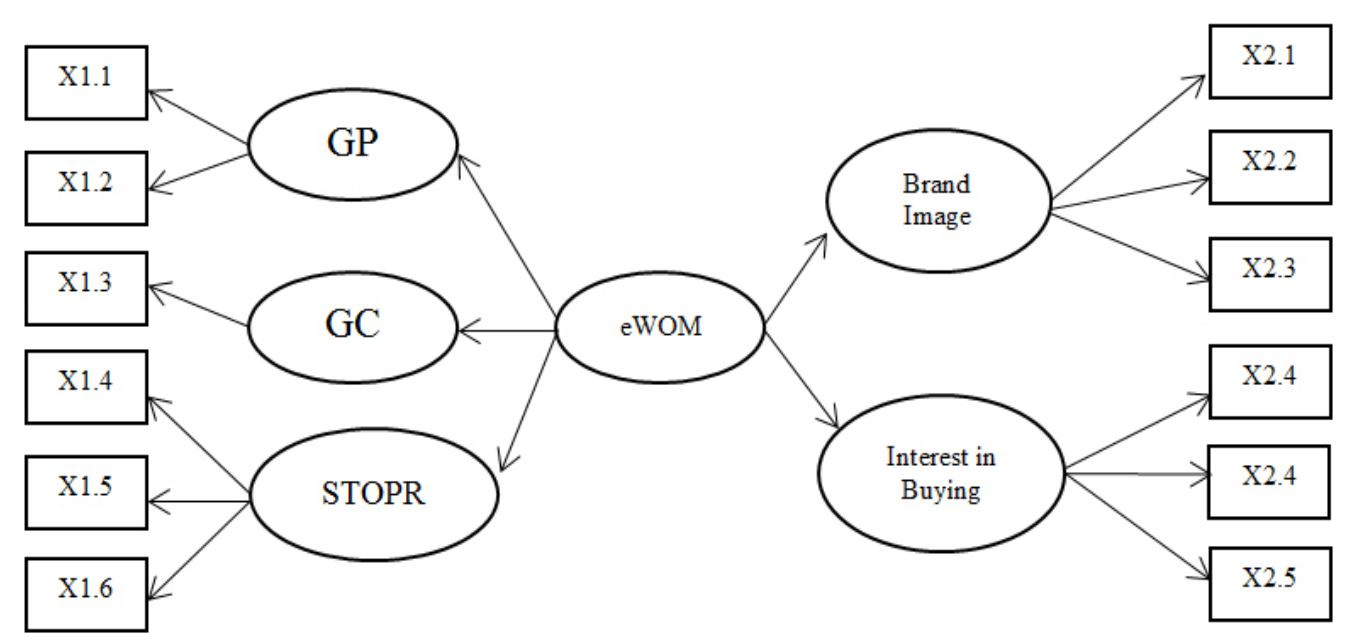

Figure 1. Research framework 


\section{RESULTS}

\section{Respondent Profile}

The demographic profile used in this research included gender, age, residence, status, educational background, occupation, income, and amount of yoghurt consumption. The results of the respondent demographic profile are presented in the following Table 1.

\section{Measurement Model Test}

Measurement model test is carried out to determine the validity of the measurement model that will be used in the research. Model measurement is considered valid if the loading score is greater than 0.6. The test was performed on each latent variable. The test results for each indicator on each latent variable are presented in the following Table 2 .

Table 2 shows that all indicators of latent variables are valid because the loading score of each indicator is above 0.6. Therefore, it is concluded that all indicators are valid. The next step is to measure the reliability of the indicators to determine the level of reliability of the indicators that will be used in this study. Reliability criteria can be measured by looking at composite

Table 1. Descriptive respondent demographic statistics

\begin{tabular}{llll}
\hline \multirow{4}{*}{ Gender } & Characteristics & $\begin{array}{c}\text { Total } \\
(\mathrm{n}=106)\end{array}$ & $\begin{array}{c}\text { Percentage } \\
(\%)\end{array}$ \\
& Man & 27 & $25 \%$ \\
Age & Woman & 79 & $75 \%$ \\
& 17-25 years & 49 & $46 \%$ \\
& 26-35 years & 56 & $53 \%$ \\
& $>36$ years & 1 & $1 \%$ \\
& Jakarta & 45 & $42 \%$ \\
Residence & Bogor & 11 & $10 \%$ \\
& Depok & 25 & $24 \%$ \\
& Tangerang & 11 & $10 \%$ \\
Status & Bekasi & 14 & $13 \%$ \\
& Married & 42 & $40 \%$ \\
Educational & Not married & 64 & $60 \%$ \\
background & Senior High School & 22 & $21 \%$ \\
& D3 & 10 & $9 \%$ \\
& S1 & 63 & \\
& S2/S3 & 11 & \\
& SOE employee & 6 & \\
\hline
\end{tabular}

reliability values and average variance extracted (AVE). The indicator is considered as reliable or able to measure the indicator if the composite reliability value is $>0.7$ and AVE value $>0.5$.

Based on Table 3, it is concluded that all indicators meet the reliability criteria and are considered capable of measuring the indicators. This is indicated by all composite reliability values above 0.7 and all AVE values above 0.5 as recommended criteria. The results of the evaluation of the measurement model in Tables 2 and 3 show that the overall data can be used, so that the research findings can be considered valid and reliable.

\section{Evaluation of Structural Models (Inner Model)}

Inner model or structural model testing is carried out to find the R-square, the correlation of indicators, and the significance value of the research model. Based on Table 4, the structural model shows the R-square value of the brand image variable of 0.181055 or $18 \%$, which means that the model can explain the brand image by $18.10 \%$ and the rest is explained by other variables outside the model. Meanwhile, the R-square of the interest in buying is 0.318442 or $31.84 \%$, which means that the variables in the model can explain the interest in buying as much as $31.84 \%$ and the rest is explained by other variables that are not examined in

\begin{tabular}{|c|c|c|c|}
\hline & Characteristics & $\begin{array}{c}\text { Total } \\
(\mathrm{n}=106)\end{array}$ & $\begin{array}{c}\text { Percentage } \\
(\%)\end{array}$ \\
\hline \multirow{4}{*}{ Occupation } & Private employee & 51 & \\
\hline & Housewife & 4 & \\
\hline & Lawyer & 2 & \\
\hline & Civil servant & 7 & \\
\hline \multirow{8}{*}{ Income } & Entrepreneur & 4 & \\
\hline & Student & 28 & \\
\hline & $<$ IDR $1,000,000$ & 17 & \\
\hline & $\begin{array}{l}\text { IDR } 1,000,000- \\
\text { IDR } 3,000,000\end{array}$ & 17 & \\
\hline & $\begin{array}{l}\text { IDR } 3,000,000- \\
\text { IDR 5,000,000 }\end{array}$ & 23 & \\
\hline & $\begin{array}{l}\text { IDR 5,000,000 - } \\
\text { IDR 10,000,000 }\end{array}$ & 45 & \\
\hline & $>$ IDR $10,000,000$ & 4 & \\
\hline & $<2 /$ week & 96 & \\
\hline \multirow{2}{*}{$\begin{array}{l}\text { Amount } \\
\text { of yogurt } \\
\text { consumption }\end{array}$} & 3 - 5 / week & 1 & \\
\hline & $>6$ / week & 9 & \\
\hline
\end{tabular}


Table 2. Test results for validity of measurement models

\begin{tabular}{|c|c|c|c|c|}
\hline \multirow{2}{*}{ Variables } & \multirow{2}{*}{ Dimension } & \multirow{2}{*}{ Indicators } & \multicolumn{2}{|c|}{ Results } \\
\hline & & & Loading Score & Convergent Validity $(>0.6)$ \\
\hline \multirow[t]{6}{*}{ eWoM } & General Persuasiveness (GP) & $\mathrm{X} 1.1$ & 0.935610 & Valid \\
\hline & & $\mathrm{X} 1.2$ & 0.920299 & Valid \\
\hline & General Credibility (GC) & $\mathrm{X} 1.3$ & 1.000000 & Valid \\
\hline & $\begin{array}{l}\text { Susceptibility to Online } \\
\text { Product Review's (STOPR) }\end{array}$ & $\mathrm{X} 1.4$ & 0.872061 & Valid \\
\hline & & $\mathrm{X} 1.5$ & 0.883840 & Valid \\
\hline & & $\mathrm{X} 1.6$ & 0.689759 & Valid \\
\hline \multirow[t]{3}{*}{ Brand Image } & & $\mathrm{X} 2.1$ & 0.906542 & Valid \\
\hline & & $\mathrm{X} 2.2$ & 0.813955 & Valid \\
\hline & & $\mathrm{X} 2.3$ & 0.860698 & Valid \\
\hline \multirow{3}{*}{$\begin{array}{l}\text { Interest in } \\
\text { Buying }\end{array}$} & & Y.1 & 0.860698 & Valid \\
\hline & & Y.2 & 0.909381 & Valid \\
\hline & & Y.3 & 0.918125 & Valid \\
\hline
\end{tabular}

Table 3. AVE, composite reliability, and cronbach's alpha value

\begin{tabular}{lccc}
\hline Variables & AVE & Composite reliability & Cronbach's alpha \\
\hline eWoM & 0.530111 & 0.870595 & 0.821623 \\
General credibility & 1.000000 & 1.000000 & 1.000000 \\
General persuasiveness & 0.861159 & 0.925396 & 0.839186 \\
Susceptibility to online product review's & 0.67248 & 0.8589 & 0.74855 \\
Brand image & 0.74171 & 0.89582 & 0.82691 \\
Interest in buying & 0.785775 & 0.916538 & 0.862454 \\
\hline
\end{tabular}

Table 4. R-Square value

\begin{tabular}{lcc}
\hline Variables & R-Square & Percentage \\
\hline eWoM & - & - \\
Brand Image & 0.18106 & $18 \%$ \\
Interest in Buying & 0.318442 & $31 \%$ \\
\hline
\end{tabular}

this research.

Contribution of Dimensions to e-WOM Variable

The research findings found that the general credibility, general persuasiveness, and susceptibility to online product review's dimensions are indicators that significantly contribute to e-WOM variable. The dimensions of general persuasiveness and general credibility have the smallest contribution with loading factor values of 0.794 and 0.813 . These values indicate that these dimensions provide the smallest relative contribution level to the e-WOM variable (Table 5).

Furthermore, Table 5 shows the largest dimension contribution, i.e. "susceptibility to online product review's" with a loading factor of 0.845 , indicating that online reviews are very sensitive. Thus, positive and negative reviews can quickly spread to potential customers and have a direct impact on consumer perceptions of the products being reviewed.

Contribution of Indicators to General Persuasiveness Dimension

Based on the results of PLS calculations presented in Table 6, indicators for general persuasiveness that show the smallest value is X1.2, i.e. "to ensure me in buying Heavenly Blush products, I often read other consumer product reviews online" with loading factor value of 0.936 . In addition, the biggest indicator value is X1.1, namely "I often read other consumer's online reviews of Heavenly Blush products to find out 
which products have a good/positive impression" with loading factor value of 0.920 . This shows that online reviews of products with a good impression have the greatest contribution to the dimensions of general persuasiveness.

Contribution of Indicator to General Credibility Dimension

Based on the results of PLS calculations presented in Table 7, the indicator X1.3, namely "when I buy Heavenly Blush products, consumer online product reviews make me confident in buying these products (credible)", gives contribution of loading factor value of 1.000 to general credibility. It shows that reading online reviews about Heavenly Blush products can increase consumer confidence in buying these products.
Contribution of Indicator to Susceptibility to Online Product Review's Dimension

Based on the results of PLS calculations presented in Table 8, the smallest indicator value on the susceptibility to online product review's dimension is X1.6, i.e. "I often consult with other consumer product reviews to help me choose the right product" with a factor loading value of 0.690 . Meanwhile, the biggest indicator value is $\mathrm{X} 1.5$, i.e. "to ensure me in buying the right product, I often read online product reviews from other consumers" with a factor loading value of 0.884 . It shows that reading online product reviews frequently can help consumers buy the right product and have the greatest contribution to the susceptibility to online product review's dimension.

Table 5. Contribution of dimensions to eWOM variable

\begin{tabular}{llcr}
\hline \multirow{2}{*}{ Variable } & \multicolumn{2}{c}{ Dimensions } & Results \\
\cline { 3 - 4 } eWOM & General persuasiveness & 0.793835 & Convergent validity \\
& General credibility & 0.812727 & Valid \\
& Susceptibility to online product review's & 0.845162 & Valid \\
& & & Valid \\
\hline
\end{tabular}

Note: Loading Factor $>0.6=$ Valid

Table 6. Contribution of indicators to general persuasiveness dimension

\begin{tabular}{llccc}
\hline \multirow{2}{*}{ Variable } & \multirow{2}{*}{ Dimension } & Indicators & \multicolumn{2}{c}{ Results } \\
\cline { 3 - 5 } & General persuasiveness & X1.1 & Loading score & Convergent validity $(>0.6)$ \\
\hline \multirow{2}{*}{ eWoM } & X1.2 & 0.935610 & Valid \\
& & 0.920299 & Valid \\
\hline
\end{tabular}

Note: Loading Factor $>0.6=$ Valid

Table 7. Contribution of indicator to general credibility dimension

\begin{tabular}{lcccc}
\hline \multirow{2}{*}{ Variable } & Dimension & Indicators & \multicolumn{2}{c}{ Results } \\
\cline { 4 - 5 } & & & Loading score & Convergent validity $(>0.6)$ \\
\hline eWoM & General credibility & $\mathrm{X} 1.3$ & 1.000000 & Valid \\
\hline
\end{tabular}

Note: Loading Factor $>0.6=$ Valid

Table 8. Contribution of indicator to susceptibility to online product review's dimension

\begin{tabular}{lllrr}
\hline \multirow{2}{*}{ Variable } & \multicolumn{1}{c}{ Dimension } & Indicators & \multicolumn{2}{c}{ Results } \\
\cline { 3 - 5 } eWoM & Susceptibility to online & X1.4 & Loading score & Convergent validity $(>0.6)$ \\
& product review's & X1.5 & 0.872061 & Valid \\
& & X1.6 & 0.883840 & Valid \\
& & 0.689759 & Valid \\
\hline
\end{tabular}

Note: Loading Factor $>0.6=$ Valid 


\section{Contribution of Indicator to Brand Image Variable}

The research shows that excellence, strength, and uniqueness of brand associations are indicators that contribute to the brand image variable. Based on Table 9 , on the brand image variable, the contribution of the indicator that has the smallest value is the strength of brand associations with a loading factor of 0.814 . This value shows that this indicator provides the smallest level of contribution to the brand image.

Furthermore, the indicator with the largest contribution to the brand image variable is the excellence of brand association with a loading factor of 0.907 . This value indicates that the Heavenly Blush brand is well remembered by yoghurt consumers directly; the more it is remembered in the minds of consumers, the better the brand image. It will certainly increase consumer interest to buy and try Heavenly Blush products.

Contribution of Indicator to Interest in Buying Variable

The research findings showed that interest in seeking product information, the desire to try, and the desire to buy the products are indicators that give contribution to the interest in buying. The loading factor value of 0.829 is the smallest contribution value indicator; i.e. the indicator of interest in seeking product information. It means that these indicators provide the smallest level of contribution to interest in buying.

Table 10 shows that the biggest contribution indicator in this variable is the indicator of the desire to buy the product with a value of 0.918 . After reading online reviews, there is interest in the minds of consumers to buy yoghurt products. The better the reviews of yoghurt products in online discussion, the more the consumers are interested in buying these yoghurt products. On the other hand, if the review of yoghurt products in online discussion is not good, it will reduce the interest of consumers to buy yoghurt products.

\section{Hypothesis Testing}

The results of hypothesis testing for structural models can be seen in Table 11. Significant levels of each correlation between latent variables can be seen from $\mathrm{t}$-calculate value that must be greater than t-table $\left(1.65^{*}\right.$ / 1.96**) for significance effects and t-count that must be smaller than t-table for non-significance effects (Gozali, 2008).

Table 9. Contribution of indicator to brand image variable

\begin{tabular}{cccc}
\hline \multirow{2}{*}{ Variable } & \multirow{2}{*}{ Indicators } & \multicolumn{3}{c}{ Results } \\
\cline { 3 - 4 } & & Loading score & Convergent Validity \\
\hline Brand Image & X2.1 & 0.906542 & Valid \\
& X2.2 & 0.813955 & Valid \\
& X3.3 & 0.860698 & Valid \\
\hline
\end{tabular}

Note: Loading Factor $>0.6=$ Valid

Table 10. Contribution of indicator to interest in buying variable

\begin{tabular}{cccc}
\hline \multirow{2}{*}{ Variable } & \multirow{2}{*}{ Indicators } & \multicolumn{2}{c}{ Results } \\
\cline { 3 - 4 } & & Loading score & Convergent Validity \\
\hline Interest in Buying & Y.1 & 0.860698 & Valid \\
& Y.2 & 0.909381 & Valid \\
& Y.3 & 0.918125 & Valid \\
\hline
\end{tabular}

Note: Loading Factor $>0.6=$ Valid

Table 11. The results of hypothesis testing

\begin{tabular}{lcl}
\hline \multicolumn{1}{c}{ Variable } & Path Coefficient & t-calculate \\
\hline Brand Image $\rightarrow$ Interest in Buying & 0.224438 & $1.748586^{*}$ \\
eWoM $\rightarrow$ Brand Image & 0.425506 & $4.223320^{* *}$ \\
eWoM $\rightarrow$ Interest in Buying & 0.430989 & $4.259855^{* *}$ \\
\hline
\end{tabular}

Note: $*$ T-table $(0.10)=1.647 \quad * *$ T-table $(0.05)=1.964$ 
Based on the Table 11, e-WOM variable directly and significantly affects the interest in buying at the $95 \%$ level of confidence. Meanwhile, if it is moderated by brand image variable, the e-WOM variable is significant to the brand image variable at the $95 \%$ level of confidence. However, the brand image variable only has a significant effect on the $90 \%$ level of confidence of the interest in buying. Furthermore, the conclusion of all tests is that the hypothesis is accepted in which it gives a significant effect.

\section{Effect of e-WOM and Brand Image Variables}

This research found a positive effect between e-WOM on brand image variables of 0.425 . It shows that online media is a fairly easy place that has a very broad network. It is operated by consumers to see reviews from family, relatives, and people around them about the experience in using a product and of course, it has an effect on the brand image of the product they use. This research is in line with the findings of research conducted by Jalilvand and Samiei (2012) that there is a positive effect between e-WOM on brand image variables.

\section{Effect of e-WOM and Interest in Buying Variables}

This research showed that e-WOM variable has a positive effect on interest in buying Heavenly Blush products with an effect value of 0.430 . It shows that online reviews from consumers on social media and chatting media can encourage interest in trying and buying yoghurt products. This research is in line with the research conducted by Laksmi and Oktavani (2016) that e-WOM has direct effect on buying interest. Their findings showed that e-WOM and interest in buying have been proven to affect each other.

\section{Effect of Brand Image on Interest in Buying Variable}

Brand image is the last variable that has a positive effect on interest in buying with an effect value of 0.224 . This variable shows that good brand image such as "easy to remember, familiar, and have special characteristics" encourage interest in buying Heavenly Blush products. This research is in accordance with the findings of the research of Gozali and Ruslim (2012) who found that there is a significant effect of brand image on interest in buying. This research explained that consumers who provide recommendations for a product will strengthen the brand image and also strengthen the intensity of interest in buying of other consumers.

\section{Managerial Implications}

The research findings revealed the effect of e-WOM on brand image and interest in buying. For marketers of Heavenly Blush products, these findings can be used as a reference for marketing strategies based on new consumer habits in accessing the internet and reading product reviews. For instance, marketers can create conditions where old consumers are encouraged to review these Heavenly Blush products with gift offers. The more the people review and recommend to others, the higher the consumer's interest in buying Heavenly Blush yoghurt products.

In addition, the effect of consumer's habits on accessing the internet and reading product reviews is the increase in brand image of Heavenly Blush products. Brand image is formed from consumer perceptions of the product. Online reviews made by old consumers illustrate the results of their perceptions after consuming these products. This will form a distinctive brand image in the consumers' point of views from its excellence, strength, and uniqueness. Consumers who provide recommendations on a product will strengthen the brand image of the product, and this brand image that strengthens consumer recommendations for increased purchase intention.

This research also illustrates the importance of using internet as a marketing communication medium. The ease of access that can reach a wide network is a great potential for marketers to promote their products using current strategies. The trend of reviewing and recommending to friends through social media or media chat is growing rapidly. Thus, many start-up companies use it as the basis for implementing their initial promotion strategy.

\section{CONCLUSIONS AND RECOMMENDATIONS}

\section{Conclusions}

Conclusions that can be drawn from this research include: 1) there is a positive effect between e-WOM variable on brand image variable of 0.425 . It shows that 
online media is a place that is quite easy and has a very broad network to see reviews from family, relatives and people around to experience using a product which affects the brand image of the products they consume, 2) e-WOM variable has a positive effect on interest in buying Heavenly Blush products with an effect value of 0.430. It shows that online reviews from reviewers on social media and chatting media can encourage interest in trying and buying yoghurt products, 3) brand image has a positive effect on buying interest with an effect value of 0.224 . It shows that a good brand image such as "easy to remember, familiar, and has special characteristics" encourages interest in buying Heavenly Blush products.

\section{Recommendations}

In terms to develop a marketing strategy, the application of managerial implications can be carried out as a basis for further strategies by taking into account the patterns of new e-WOM consumer habits. For instance, accessing the internet and reading product reviews, as well as the implications of brand image from Heavenly Blush products that are good enough can affect consumers' interest in buying the product. Furthermore, in completing and refining the findings of this research, the researchers suggest future research to use additional potential variables that can be used as marketing strategies.

\section{REFERENCES}

[APJII] Asosiasi Penyelenggaran Jasa Internet Indonesia. 2018. Penetrasi \& Prilaku Pengguna Internet Indonesia Survey 2017. Jakarta: APJII.

Ambarwati MS, Mawardi MK. 2015. Pengaruh citra merek terhadap minat membeli (survei pada mahasiswa universitas brawijaya yang menggunakan pasta gigi pepsodent). Jurnal Administrasi Bisnis (JAB) 25(1):1-7.

Chan YYY, Ngai EWT. 2011. Conceptualizing electronic word of mouth activity. Marketing Intelligence and Planning 29: 488-516. https:// doi.org/10.1108/02634501111153692.

Charo N, Sharma P, Shaikh S, Haseeb A, Sufya MZ. 2015. Determining theimpact of e-wom on brand image and purchase intention through adoption of online opinions. International Journal of Humanities and Management Sciences 3(1): 41-46.
Cheema A, Kaikati AM. 2010. The effect of need for uniqueness on word of mouth. Journal of Marketing Research 47(3): 553-563. https://doi. org/10.1509/jmkr.47.3.553.

Ejtahed HS, Mohtadi-Nia J, Homayouni-Rad A, Niafar M, Asghari-Jafarabadi M, Mofid V. 2012. Probiotic yoghurt improves antioxidant status in type 2 diabetic patients. Nutrition Jurnal 28: 539543. https://doi.org/10.1016/j.nut.2011.08.013.

Gozali I. 2008. SEM Metode Alternatif dengan PLS. Semarang: Badan Penerbit Universitas Diponogoro.

Gozali MY, Ruslim TS. 2012. Efek E-WOM Terhadap Brand Image dan Purchase Intention (Kasus : Industri Mobil "D”). Jakarta: Fakultas Ekonomi Universitas Tarumanegara.

Jalilvand MR, Samiei N. 2012. The effect of electronic word of mouth on brand image and purchase intention. Marketing Intelligence \& Planning 30(4): 460-476. https://doi. org/10.1108/02634501211231946.

Jatmika CS. 2014. Pengaruh electronic word of mouth terhadap brand image \& purchase intention smartphone samsung di Surabaya. Calypta: Jurnal Ilmiah Mahasiswa Universitas Surabaya 3(2):1-15.

Kartika C, Piranti D. 2015. Pengaruh electronic word of mouth (eWOM) twitter @ batikair terhadap brand image. Jurnal Visi Komunikasi 14(1): 104116.

Kotler P, Keller KL. 2011. Manajemen Pemasaran. Edisi 13 Jilid 1 dan 2 Alih Bahasa Bob Sabran. Jakarta: Erlangga.

Laksmi AA, Oktafani F. 2016. Pengaruh electronic word of mouth (eWOM) terhadap minat membeli follower instagram pada warunk upnormal. Jurnal Computech \& Bisnis 11(1):1-12.

Maisam S, Mahsa R. 2016. Positive word of mouth marketing: explaining the roles of value congruity and brand love. Journal of Competitiveness 8(1): 19-37. https://doi.org/10.7441/joc.2016.01.02.

Mehmood T, Liland KH, Snipen L, Sæbø S. 2012. A review of variable selection methods in partial least squares regression. Chemometrics and Intelligent Laboratory Systems 118: 62-69. https://doi.org/10.1016/j.chemolab.2012.07.010.

Needs EC, Capellas M, Bland AP, Manoj P, Macdougal D, Paul G. 2000. Comparison of heat and pressure treatments of skim milk, fortified with whey protein concentrate, for set yoghurt preparation: effects on milk proteins and gel structure. Journal 
of Dairy Research 67(3): 329-348. https://doi. org/10.1017/S0022029900004301.

Rachman IS, Hubeis AVS, Motik SSF. 2017. Strategi peningkatan brand loyalty dan customer satisfaction bisnis yoghurt di Indonesia (studi kasus: PT. Yummy Food Utama). Jurnal Aplikasi Bisnis dan Manajemen 3(2): 324-333. https:// doi.org/10.17358/jabm.3.2.324.

Resnawati H. 2014. Kualitas susu pada berbagai pengolahan dan penyimpanan. Jurnal Ilmu Ternak dan Veteriner 19(2):497-502.

Samuel H, Lianto AS. 2014. Pengaruh Analisis eWOM, brand image, brand trust dan minat beli produk smartphone di Surabaya. Jurnal Universitas Kristen Petra Surabaya 8(2):47-54.

Sanny L. 2011. Analisis industri pengolahan susu di Indonesia. Binus Business Review 2(1): 81-87. https://doi.org/10.21512/bbr.v2i1.1112.

Sumarwan U, Jauzi A, Mulyana A, Karno BN, Mawardi PK, Nugroho W. 2011. Riset Pemasaran dan Konsumen Seri I. Bogor: Penerbit IPB Press.

Talbot M. 1997. Partial Least Square Regression. New York: Corp Csi.

Tongco MDC. 2007. Purposive sampling as a tool for informant selection. Ethnobotany Research and Applications 5: 147-158. https://doi. org/10.17348/era.5.0.147-158.

Yamin S, Kurniawan H. 2009. Structural Equation Modelling: Belajar Lebih Mudah Teknik Analisis Data Kuesioner dengan Lisrel - PLS. Jakarta: Salemba Infotek.

Yoo B, Donthu N, Lee S. 2000. An examination of selected marketing mix elements and brand equity. Journal of the academy of marketing science 28(2): 195-211. https://doi. org/10.1177/0092070300282002. 